\title{
Leonarda Mariak
}

Uniwersytet Szczeciński

\section{Funkcja ekspresywna leksyki z zakresu medycyny w listach prywatnych Henryka Sienkiewicza ${ }^{1}$}

W obszernym ${ }^{2}$ i różnorodnym pod względem podejmowanej problematyki korpusie listów rodzinnych Henryka Sienkiewicza ważne miejsce zajmują zagadnienia zdrowotne. $Z$ analizy treści oraz warstwy leksykalnej listów wynika, że zdrowie własne, znajomych i przede wszystkim członków rodziny było dla pisarza tematem nadrzędnym, podejmowanym prawie w każdym liście ${ }^{3}$.

${ }^{1}$ Niniejszy artykuł jest kontynuacją rozważań poświęconych funkcji leksyki medycznej w listach Henryka Sienkiewicza zawartych w artykule: Funkcja informacyjna leksyki z zakresu medycyny w listach prywatnych Henryka Sienkiewicza, w: Leksyka języków stowiańskich w badaniach synchronicznych i diachronicznych, red. M. Gębka-Wolak, J. Kamper-Warejko, A. Moroz, Torun 2014, s. 217-241.

${ }^{2}$ Zachowana korespondencja rodzinna Sienkiewicza obejmuje obszerny, liczący ponad 1400 zbiór listów pisanych do członków rodziny, czyli trzech kolejnych żon: Marii z Szetkiewiczów (dalej: MSz) - 10 listów, Marii z Wołodkowiczów (dalej: MW) - 6 listów, Marii z Babskich (dalej: MB) - 600 listów, dwojga dzieci: córki Jadwigi (dalej: JS) - 92 listy, syna Henryka Józefa (dalej: HJS) - 66 listów, siostry Heleny (dalej: HS) - 64 listy oraz szwagierki Jadwigi z Szetkiewiczów Janczewskiej (dalej: JJ) - 563 listy. Łącznie korespondencja rodzinna Sienkiewicza zajmuje blisko 3 tys. stron druku w wydaniu zbiorowym korespondencji Sienkiewicza, pod redakcją Marii Bokszczanin [zob. Henryk Sienkiewicz, Listy, t. 2, cz. 1: Jadwiga i Edward Janczewscy, oprac. M. Bokszczanin, Warszawa 1996; t. 2, cz. 2: Jadwiga i Edward Janczewscy, oprac. M. Bokszczanin, Warszawa 1996; t. 2, cz. 3: Jadwiga i Edward Janczewscy, oprac. M. Bokszczanin, Warszawa 1996; t. 4, cz. 1: Maria z Szetkiewiczów Sienkiewiczowa Maria z Wołodkowiczów Sienkiewiczowa - Maria z Babskich Sienkiewiczowa (1888-1907), oprac. M. Bokszczanin, Warszawa 2008; t. 4, cz. 2: Maria z Babskich Sienkiewiczowa (19081913), oprac. M. Bokszczanin, Warszawa 2008; t. 4, cz. 3: Henryk Józef Sienkiewicz - Jadwiga Sienkiewiczówna - Helena Sienkiewiczówna - Lucjan Sienkiewicz, oprac. M. Bokszczanin, Warszawa 2008].

${ }^{3}$ Wyjątkiem są tu np. depesze lub listy bardzo krótkie, o charakterze telegramu lub aneksu, w których Sienkiewicz pisał o sprawach pilnych, np. o czasie przyjazdu, niespodziewanej wizycie, 
Oprócz funkcji informacyjnej użyta przez Sienkiewicza leksyka z zakresu medycyny pełni w listach funkcję ekspresywną $\mathrm{i}$ wartościującą. Najczęściej mamy do czynienia z ekspresją dwubiegunową - dodatnią, gdy pisarz informował o pozytywnych skutkach kuracji, dobrym zdrowiu, oraz ujemną, gdy donosił o czyjejś chorobie, niepomyślnych rokowaniach leczenia. Repertuar środków językowych służących wyrażeniu emocji jest zróżnicowany i obejmuje przede wszystkim połączenia nominalne $\mathrm{z}$ nacechowanymi przymiotnikami (imiesłowami) oraz zwroty z przysłówkami o wartości ekspresywnej.

Tabela 1. Wyrażenia i zwroty nacechowane ekspresywnie

\begin{tabular}{|c|c|}
\hline Ekspresja negatywna & Ekspresja pozytywna \\
\hline $\begin{array}{l}\text { 1. Wyrażenia z przymiotnikiem } \\
\text { (imiesłowem) o ewaluacji ujemnej: }\end{array}$ & $\begin{array}{l}\text { 1. Wyrażenia z przymiotnikiem } \\
\text { (imiesłowem) o ewaluacji dodatniej: }\end{array}$ \\
\hline $\begin{array}{l}\text { anemia wielka (HS, 1901, 25)5; } \\
\text { bol ubezwładniajacy (JJ, 1890, 214); } \\
\text { boleści silne (JJ, 1897, 448); } \\
\text { ból głowy bardzo niemity (MB, 1906, } \\
\quad \text { 169), ogromny (JJ, 1894, 361); } \\
\text { bóle bardzo nieprzyjemne } \\
\text { (MB, 1911, 460), przykre, } \\
\text { deprymujące (JS, 1908, 14); } \\
\text { bronchita silna (JJ, 1894, 376); }\end{array}$ & $\begin{array}{l}\text { humor dobry (JJ, 1887, 89); } \\
\text { kąpiel rozkoszna }(\mathrm{HS}, 1897,13) \text {; } \\
\text { samopoczucie coraz lepsze } \\
\quad(\mathrm{MB}, 1909,331) \\
\text { świetne }(\mathrm{MB}, 1909,326) \text {; } \\
\text { sen smaczny }(\mathrm{JJ}, 1887,89) \text {; } \\
\text { stan kwitnacy (MB, 1904, 104); } \\
\text { zdrowie dobre }(\mathrm{MB}, 1904,98) \text {, } \\
\quad \text { niezłe }(\mathrm{JJ}, 1892,301) .\end{array}$ \\
\hline
\end{tabular}

oraz listy dłuższe, ale w całości poświęcone jednemu zagadnieniu, np. literaturze, twórczości, sprawom społecznym, politycznym itp. (Taki charakter ma spora grupa korespondencji adresowanej do szwagierki - Jadwigi Janczewskiej).

${ }^{4} \mathrm{Na}$ użytek tej pracy przyjmuje się za Stanisławem Grabiasem (O ekspresywności języka. Ekspresja a stowotwórstwo, Lublin 1981, s. 19-40), Arturem Rejterem (Leksyka ekspresywna $w$ historii języka polskiego. Kulturowo-komunikacyjne konteksty potoczności, Katowice 2006, s. 57-71) oraz Renatą Grzegorczykową (Struktura semantyczna wyrażeń ekspresywnych, w: Z zagadnień słownictwa wspótczesnego języka polskiego, red. M. Szymczak, Warszawa 1979, s. 118) definicje pojęć: „ekspresja”, „ekspresywność”, ,emocjonalność”, „wartościowanie”. „Ekspresja" to 'proces uzewnętrzniania osobowości nadawcy'; „ekspresywność” jest 'cechą znaku będącą wynikiem procesu ekspresji'; ,emocjonalność” stanowi 'uczuciowy stosunek nadawcy do rzeczywistości' ( $w$ tekście artystycznym narratora oraz bohaterów utworu wobec innych postaci literackich i/lub elementów świata przedstawionego), wyrażony za pomocą różnych środków językowych. „Ekspresja” i „ekspresywność” cechuje teksty, których główną funkcją nie jest przekazywanie informacji, lecz wyrażanie stanów i uczuć z zamiarem wywołania analogicznych uczuć i stanów u odbiorcy. Wyrażaniu „ekspresji” towarzyszy zwykle ocena pozytywna lub negatywna. Ma to bezpośredni związek z zawartym w ekspresywnym znaku językowym komponentem wartościującym, wyrażającym się w ramie modalnej: sądzę, że wiesz, że to dobrze/źle.

${ }^{5} \mathrm{~W}$ nawiasach podano inicjały adresatów natomiast liczby oznaczają odpowiednio rok powstania listu i jego numer w kolejnym tomie (zob. przyp. 2). 


\begin{tabular}{|c|c|}
\hline Ekspresja negatywna & Ekspresja pozytywna \\
\hline $\begin{array}{l}\text { choroba mózgowa ciężka } \\
\text { (MB, 1909, 371); } \\
\text { chory najciężej (JS, 1908, 18); } \\
\text { febra podła (JJ, 1891, 284); } \\
\text { gardło dość marne (JS, 1908, 19), } \\
\text { marne (JS, 1908, 19); } \\
\text { gniecenie pod dołkiem nadzwyczaj } \\
\quad \text { mocne (MB, 1909, 346); } \\
\text { gorączka bardzo silna (JJ, 1894, 403), } \\
\text { silna (MB, bez daty, 593); } \\
\text { influenca nadzwyczaj silna } \\
\text { (MB, 1906, 151); } \\
\text { katar bardzo lekki (MB, 1908, 305), } \\
\text { bardzo mocny (JJ, 1894, 366), } \\
\text { ogromny (JJ, 1900, 472), } \\
\text { okropny (JJ, 1893, 337), potężny } \\
\text { (JS, 1908, 15), straszny (JJ, 1886, 21); } \\
\text { katar żołądka ostry (JJ, 1890, 261); } \\
\text { lumbago niegodziwe (HS, 1908, 37); } \\
\text { migrena szalona (JJ, 1890, 215), } \\
\text { brzydka (JJ, 1887, 71); } \\
\text { newralgia bolesna (MB, 1903, 67), } \\
\text { ciężka (MB, bez daty, 564), } \\
\text { okrutna (HS, 1903, 35); } \\
\text { osłabienie wielkie (HS, 1904, 36); } \\
\text { paratyfuzin wielce dobrotliwy } \\
\text { (MB, 1910, 398); } \\
\text { stan gorszy (MB, 1908, 265); } \\
\text { stan nerwów nieszczególny } \\
\text { (MB, 1911, 435); } \\
\text { trawienie złe (JHS, 1912, 60); } \\
\text { mysięk ogromny (JJ, 1890, 238); } \\
\text { mieszczególne (JS, 1908, 17). } \\
\text { zapalenie gardła mocne (MB, 1904, 85); } \\
\text { zapalenie płuc ciężkie (JJ, 1889, 193); } \\
\text { zdrowie liche (JS, 1908, 14), } \\
\text { marne (JJ, 1892, 305), }\end{array}$ & \\
\hline $\begin{array}{l}\text { 2. Zwroty z przysłówkiem } \\
\text { o ewaluacji ujemnej: } \\
\text { boleć okropnie (MB, 1905, 109); } \\
\text { chorować bardzo poważ- } \\
\text { nie (JS, 1908, 17); }\end{array}$ & $\begin{array}{l}\text { 2. Zwroty z przysłówkiem } \\
\text { o ewaluacji dodatniej: } \\
\text { być z gardłem kanibalsko } \\
\text { dobrze (MB, 1904, 87); } \\
\text { czuć się wybornie ( JJ, 1887, 68); }\end{array}$ \\
\hline
\end{tabular}




\begin{tabular}{|l|c|}
\hline Ekspresja negatywna & Ekspresja pozytywna \\
\hline chrypieć ogromnie (JJ, 1898, 463); & wyglądać dobrze (MB, 1905, 137), \\
czuć się mocno osłabionym & świetnie (MB, 1910, 389); \\
$\quad$ (JHS, 1914, 66), niestychanie & znaleźć (kogo) doskonale (Dtuski badat \\
$\quad$ ostabionym (JS, 1910, 52); & Dzinkę przeszło godzine - i znalazt \\
kaszlać strasznie (MB, 1904, 86); & ja doskonale; MB, 1907, 222). \\
niedomagać mocno (MB, 1908, 279); & \\
sypiać nieszczególnie (MB, 1909, & \\
353; MB, 1911, 142); & \\
wyglądać ogromnie mizer- & \\
nie (JHS, 1907, 43). & \\
\hline
\end{tabular}

Jak widać z zaprezentowanych przykładów, odmienne postaci użytych przez Sienkiewicza określeń waloryzujących mają różny stopień intensyfikacji cechy. Zwiększeniem wartości ekspresywnej odznaczają się wyrażenia z przysłówkami typu: bardzo, nadzwyczaj, wielce, dość, mocno, ogromnie podkreślającymi intensywność cechy nazywanej w wyrazach, z którymi się łączą, np. bóle bardzo nieprzyjemne (MB, 1911, 460), katar bardzo mocny (JJ, 1894, 366), bardzo lekki (MB, 1908, 305), bardzo niemity ból głowy (MB, 1906, 169), gorączka bardzo silna (JJ, 1894, 403), nadzwyczaj mocne gniecenie pod dołkiem, (MB, 1909, 346), nadzwyczaj silna influenca (MB, 1906, 151), paratyfuzin wielce dobrotliwy (MB, 1910, 398), gardło dość marne (JS, 1908, 19), wyglądać ogromnie mizernie (JHS, 1907, 43). Ze zjawiskiem intensyfikacji cechy mamy do czynienia również w przypadku wyrażeń, w których skład weszły przymiotniki i przysłówki o wyraźnie widocznej dodatniej lub ujemnej wartości semantycznej, np. (intens. dodatnia) doskonale, porzadnie, rzetelnie, wybornie, dobry, rozkoszny, świetny; (intens. ujemna) bolesny, brzydki, deprymujacy, marny, niegodziwy, okrutny, podty, przykry, nieszczególnie, strasznie itp. Wśród zgromadzonych form określających odnotowano stosunkowo niewielki udział przymiotników i przysłówków w stopniu wyższym i najwyższym - np. (kto) najzdrowszy, najsilniejszy (JJ, 1886, 31), stan gorszy (MB, 1908, 265), chory najciężej (JS, 1908, 18) - oraz konstrukcji porównawczych: najzdrowszy w świecie (JJ, 1894, 363), zdrowszy od nas wszystkich (JJ, 1894, 365).

Przymiotnikami nacechowanymi ekspresywnie, zróżnicowanymi pod względem dyferencjału emocjonalnego Sienkiewicz posłużył się również w charakterystyce ludzi. I tak osoby zdrowe przedstawiał za pomocą przymiotników (imiesłowów) waloryzujących dodatnio, takich jak: zdrowy (JJ, 1908, 21), kwitnący (MB, 1904, 104), raźny (MB, 1908, 265), rzeźwy (JS, 1913, 72), zupetnie zdrowy (JJ, 1890, 245). Czasami, dla podkreślenia pozytywnych emocji, używał określników w postaci kilkuelementowych szeregów: rumiany, silny (JJ, 1889, 137), zdrowy, mocny, czerstwy, hoży (JJ, 1889, 183). Opisy ludzi chorych zawierają 
przymiotniki o ujemnej wartości semantycznej: mizerny (MB, 1913, 504), marny (JHS, 1902, 9), stabiutki (HS, 1901, 25), chory (MB, 1908, 238), staby i marny (JHS, 1902, 2), (kto) porzadnie chory (JS, 1904, 5), (kto) mizerny bardzo (JJ, 1890, 257), (kto) rzetelnie niezdrowy (HS, 1899, 19), (kto) mocno niezdrów (MB, 1911, 411), chory w wysokim stopniu (JJ, 1889, 178), bardzo kruchy (MB, 1911, 491).

Wszystkie wymienione tu formy atrybutywne (o konotacji dodatniej i ujemnej), z uwagi na związki uczuciowe łączące nadawcę z adresatami listów, służyły werbalizacji przede wszystkim pozytywnych uczuć, takich jak: miłość, współczucie, ubolewanie, litość, radość 6 .

Kolejną, zróżnicowaną i ciekawą kategorię nazw nacechowanych tworzą derywaty. Wśród nazw motywowanych słowotwórczo przeważają deminutywa (I i II stopnia) przynależne do dwóch grup semantycznych fundowane typowymi dla tej kategorii formantami: $-k o,-k a,-e k,-i j k a /-y j k a^{7},-i k /-y k,-k i$ :

a) zdrobnienia, określające chore części ciała:

- gardziołko (JJ, 1889, 159, 183),

- główka (JJ, 1889, 183),

- plucka (JJ, 1889, 171),

- wątróbka (JJ, 1910, 503),

- zotadeczek (JJ, 1889, 167);

b) zdrobnienia określające schorzenia, dolegliwości i ich objawy:

- apopleksyjka (JJ, 1889, 175),

- grzybki 'ziarniste gruczołki w gardle' (JJ, 1896, 432),

- humorek 'samopoczucie': „Ragaz nudne jak zawsze, a ponieważ przy tych kąpielach wyłażą z początku wszelkie dolegliwości i co bolało, to zaczyna boleć więcej, zatem i humorek będzie odpowiedni” (JS, 1911, 54),

- katareczek żołądka (JJ, 1897, 442),

- newralgijka (JJ, 1893, 340),

- paralizeczek (JJ, 1893, 383),

- paralizyk (JJ, 1889, 175),

- tyfusik (JJ, 1889, 175),

- wrzodzik (JJ, 1809, 23),

- wymiotki (JJ, 1889, 179).

Wymienione powyżej przykłady nacechowanych ekspresywnie derywatów obejmują tylko denominalne formacje zdrobniałe nacechowane pozytywnie lub negatywnie, których ekspresję podkreślał odpowiedni kontekst.

${ }^{6}$ Zob. A. Rejter, op.cit., s. 67.

7 W przypadku leksemów apopleksyjka, newralgijka przyjmuję motywację za pomocą formantu -yjka/-ijka, ponieważ poświadczone w listach formy niezdrobniałe mają postać: newralgia, apopleksja. 
Melioratywną barwę uczuciową sympatii, współczucia, uwydatniają waloryzujące dodatnio przydawki: gardziołko biedne (JJ, 1889, 159, 183), płucka kochane (JJ, 1889, 171), żołądeczek prześliczny (JJ, 1889, 167), paraliżyk lekki (JJ, 1889, 175), tyfusik niewinny (JJ, 1889, 175), wymiotki prześliczne (JJ, 1889, 179). Część z podanych form zdrobniałych podkreśla emocjonalny stosunek nie wobec desygnatu, lecz wobec osoby, której dany desygnat dotyczył, np. gardziołko, główka, płucka mają pozytywną barwę uczuciową z tego względu, że odnoszą się do Jadwigi Janczewskiej - siostry pierwszej, przedwcześnie zmarłej żony pisarza. Lektura całości prywatnej korespondencji ${ }^{8}$ wskazuje, że Sienkiewicz odnosił się do szwagierki z prawdziwą sympatią i zawsze przedstawiał ją w pozytywnym świetle.

Derywaty ekspresywno-deminutywne o ujemnej konotacji odnoszą się tylko do Sienkiewicza. Pisarz wykorzystał je, by wyrazić swój ironiczny, lekceważący stosunek do trapiących go chorób i dolegliwości: „z żoładeczkiem moim dziś smutniej niż poprzednio” (MB, bez daty, 547); „Z początku błysnęło mi w głowie, czy to nie będzie mała apopleksyjka, lekki paraliżyk lub niewinny tyfusik, myśl o testamenciku przejęła mnie drżeniem rozkoszy” (JJ, 1889, 175); „Mam się z gardłem i żołądkiem dobrze, tylko boli mnie lewa łapa. Początek paraliżeczku czy co!” (JJ, 1893, 383); „Pisać nie mogłem, żołądek popsuł mi się na nowo w wysokim stopniu, mam bole głowy, newralgijki etc." (JJ, 1893, 340); „pojawił się katareczek żołądka w nowym wydaniu” (JJ, 1897, 442). W podobnej funkcji użyte zostały formacje augmentatywne utworzone za pomocą formantu inwariantnie ekspresywnego -isko: „Zmęczenie powoli przechodzi, tylko te zębiska!" (JJ, 186, 14); ,glowisko pobolewa" (JJ, 1889, 200); a także nacechowanych synonimów: ,boli mnie lewa łapa” (JJ, 1893, 383); ,jestem ciężko chory na gardziel” (JJ, 1887, 49); „Nie przyjdę na obiad, bo paszcza mnie boli, wskutek czego jestem zły i posępny" (JJ, 1891, 537).

Przegląd blisko czterdziestoletniej korespondencji prywatnej (ponad 1400 listów) obejmującej cały okres dorosłego życia pisarza dowodzi, że cierpiał on na wiele różnych schorzeń, wśród których znalazły się m.in.: wyczerpanie nerwowe (depresja), anemia mózgu, bezsenność, bronchit, zapalenie gardła, chroniczne wrzody w gardle, chrypka, bóle artretyczne umiejscowione w różnych częściach ciała, iszjas, bóle krzyża, lumbago, żółta febra, choroby układu krążenia, arytmia, duszności, żylaki i wiele innych ${ }^{9}$. Najczęściej jednak pisarz uskarżał się na bóle zębów, bóle reumatyczne, infekcje górnych dróg oddechowych oraz zaburzenia gastryczne o różnym charakterze. Informacje na temat

${ }^{8}$ O kreacji Janczewskiej piszę w artykule: „Żaba” $i$ „,Mgła”- językowa kreacja Jadwigi Janczewskiej na podstawie listów prywatnych Henryka Sienkiewicza (w druku).

${ }^{9}$ Zob. L. Mariak, Funkcja informacyjna leksyki z zakresu medycyny..., passim. 
tych dolegliwości znajdujemy niemal w każdym liście pisanym do członków rodziny. Zważywszy na stan zdrowia Sienkiewicza i listę jego chorób, za w pełni zasadne należy uznać zastosowanie słownictwa nacechowanego ekspresywnie. Za pomocą derywatów: żołądeczek, katarek, newralgijka; zębiska, głowisko oraz nacechowanych synonimów: łapa, paszcza Sienkiewicz sygnalizował swój pobłażliwy, czasami ironiczny stosunek do własnych cierpień i dolegliwości, a tym samym łagodził treść niepomyślnych informacji na temat zdrowia.

Oprócz omówionych wcześniej atrybutywów oraz formacji słowotwórczych wartością ekspresywną odznaczają się różnego typu połączenia wyrazowe o skonwencjonalizowanym charakterze. Użyte przez Sienkiewicza frazeologizmy można podzielić na trzy grupy znaczeniowe, które określają:

1. Choroby, zły stan zdrowia, chorowanie:

a) wyrażenia:

- język pod psem: „Gorączki nie ma, ale język pod psem” (MB, bez daty, 551) (SF, t. 1, s. 673: pod psem) ${ }^{10}$,

- katar żoładka, kiszek: „Mam katar żołądka, a prawdopodobnie i kiszek” (JJ, 1892, 319) (SF, t. 2, s. 894: katar żołądka),

- usposobienie lumbagowe ${ }^{11}(\mathrm{JJ}, 1894,384)$, usposobienia scyjatyczne ${ }^{12}$ (JJ, 1894, 388) (SF, t. 2, s. 474: usposobienie - jakie?);

b) zwroty:

- podkopać/poderwać zdrowie/nerwy (JJ, 1888, 109) (SF, t. 2, s. 815: poderwać zdrowie, podkopać zdrowie),

- stracić zdrowie (JJ, 1909, 493) (SF, t. 2, s. 815: stracić zdrowie),

- nie mieć się dobrze (JJ, 1892, 307), mieć się gorzej (MB, 1903, 79)/ nieszczególnie (MB, 1911, 486) / dosyć marnie (MB, bez daty, 563) (SF, t. 1, s. 441: mieć się dobrze, doskonale, nieźle),

- mieć żoładek, nerwy nie w należytym porządku (MB, 1904, 103) (SF, t. 1, s. 724: coś nie jest w porządku),

- ledwo dyszeć (MB, 1906, 162) (SF, t. 1, s. 201: ledwo dyszeć),

- być chorym na głowę: „[...] byłem chory ciągle na głowę" (JJ, 1895, 419) (SF, t. 1, s. 136: chory na co),

- mieć bóle: „[...] miewam ogromne bóle głowy” (JJ, 1894, 361) (SF, t. 1, s. 110: mieć bóle czego),

- walczyć z gardlem: „Z gardlem walczę energicznie i myślę, że się wywinę” (JJ, 1892, 314) (SF, t. 2, s. 502: walczyć z czym),

${ }^{10}$ Zebrane frazeologizmy sprawdzono w Słowniku frazeologicznym języka polskiego Stanisława Skorupki (t. 1-2, Warszawa 1989; dalej skrót: SF).

${ }^{11}$ Lumbago - silny ból w okolicy lędźwiowej kręgosłupa, najczęściej spowodowany zapaleniem korzonków nerwowych.

${ }^{12}$ Scyjatyka - choroba polegająca na zapaleniu nerwu kulszowego, inaczej ischias. 
- klapnać na gardlo: „Czuję, że gdybym został, klapnę znowu na gardlo, więc wolę w Wiedniu" (JJ, 1894, 403) (SF, t. 2, s. 759: zapaść, zapadać na co 'zachorować na co'),

- źle sprawiać się z sercem: „Babunia zdrowa, ale Ciocia Dzinia zaczyna się znów jakoś źle sprawiać z sercem" (JS, 1908, 26) (SF, t. 2, s. 184: sprawić się z czym);

c) frazy:

- lumbago wlazło między topatki: „Moje lumbago lepiej, ale wlazło mi trochę obecnie między topatki" [...] (MB, 1911, 428) (SF, t. 2, s. 581: coś wlazło komu w kości, nogę itd.),

- „Influenca poszła mi w piersi i żołądek” (JJ, 1894, 368) (SF, t. 2, s. 581: coś wlazło komu w kości, nogę itp.; SF, t. 2, s. 678-679: co poszło komu w pięty),

- nerwy potargaty się do reszty: „Nerwy moje potargaly się do reszty i miewam ogromne bóle głowy" (JJ, 1894, 361), nerwy targaja się gorzej i gorzej (JJ, 1894, 368) (SF, t. 1, s. 494: targać nerwy),

- ,goraczka okropnie mnie zjadta” (JJ, 1894, 403) (SF, t. 1, s. 254: gorączka trawi kogo),

- „nerwy i zdrowie psuja się” (JJ, 1894, 403) (SF, t. 2, s. 816: zdrowie czyje psuje się).

2. Zabiegi, badania medyczne:

a) zwroty:

- zagladać w paszczę: „Chciał mi w paszczę zagladać, ale mu powiedziałem: «Cura te ipsum» ${ }^{13 ”}$ (JJ, 1887, 49) (SF, t. 2, s. 733: zaglądać komu w duszę, serce itd.),

- oddać paszczę do reperacji: „Zębiska trochę jeszcze dolegają [...]. Na dobrą sprawę wypadałoby zatrzymać się parę dni w Wiedniu - i oddać paszczę do reperacji" (JJ, 1887, 87) (SF, t. 2, s. 21: dać, oddać co do reperacji),

- oddać paszczę w opiekę (komu): „[...] że zębiska (te, których nie ma) bolą go to mniej, to więcej - i rad by, a raczej nierad by, ale musi oddać paszczę swoją w opiekę Cybulskiemu [dentysta - L.M.]." (JJ, 1890, 208) (SF, t. 1, s. 605: oddać kogo w opiekę komu),

- mieć chrapkę na operację: „Heryng [warszawski laryngolog - L.M.] utrzymuje, że gdyby tylko wyciąć migdały, nie wiedziałbym, co to ból gardła. Jeśli jednak ma chrapkę na operację - to próżny apetyt" (JJ, 1887, 52) (SF, t. 1, s. 137: mieć na co chrapkę),

- ząb pójdzie z interesu: „Zęby mnie pobolewają i jeden pójdzie prawdopodobnie w tych dniach «z interesu»" (JJ, 1906, 488) (SF, t. 1, s. 292: wyjść $\mathrm{z}$ interesu),

${ }^{13}$ Cura te ipsum (łac.) - odczep się od duszy mojej. 
- chuchać, dmuchać (na kogo): „Naturalnie, że będziemy na niego [syna L.M.] chuchać, dmuchać, aby doprowadzić go do pożądanego stanu sił i zdrowia" (JJ, 1899, 466) (SF, t. 1, s. 172: chuchać, dmuchać).

3. Zdrowie, brak dolegliwości:

a) zwroty:

- mieć się dobrze (JJ, 189, s. 196) / zupetnie dobrze (JJ, 1903, 481) / nieźle (JJ, 1890, 255) / lepiej (JJ, 1894, 395) / doskonale (MB, 1907, 226) (SF, t. 1, s. 441: mieć się dobrze, doskonale, nieźle itp.),

- czuć się dobrze (JJ, 1890, 247) / nieźle (JJ, 1894, 403) / zdrowym (JJ, 1908, s. 489) / zdrowszym (JJ, 1890, 261), nie czuć się chorym (MB, 1906, 200) (SF, t. 1, s. 156: czuć się dobrze, źle; czuć się zmęczonym, szczęśliwym itp.),

- pękać ze zdrowia (JJ, 1890, s. 255) (SF, t. 1, : p: przen. pękać ze złości, ze śmiechu, z gniewu),

- trzymać się dobrze (MB, 1909, 364) (SF, t. 2, s. 403: trzymać się dobrze),

- być w dobrym zdrowiu (MB, 1904, 98) (SF, t. 2, s. 815: ktoś w dobrym zdrowiu),

- być w stanie kwitnacym (MB, 1904, 104) (SF, t. 2, s. 204: być w jakim stanie)

- być dobrze z żoładkiem (JJ, 1894, 376) (SF, t. 1, s. 124: być z kim dobrze/ źle),

- wygladać tęgo (JJ, 1890, 265) (SF, t. 2, s. 652: wyglądać zdrowo, dobrze itp.);

b) fraza:

- zdrowie dopisuje (JJ, 1897, 439) (SF, t. 1, s. 181: zdrowie dopisuje komu);

c) spetryfikowane konstrukcje porównawcze:

- zdrowy jak smreczek (JJ, 1889, 174), zdrów jak ryba (JJ, 1895, 412), zdrowa jak wróbel (JJ, 1894, 363), (SF, t. 2, s. 816: zdrowy/zdrów jak np. ryba, rzepa itp.),

- wygladać jak młoda rzodkiewka (MB, 1906, 192), wygladać jak samo zdrowie (JHS, 1906, 8) (SF, t. 2, s. 653: wyglądać jak np. róża, rydz, samo zdrowie itp.).

4. Proces zdrowienia:

- przychodzić do siebie (HS, 1901, 25) (SF, t. 1, s. 773: przyjść do siebie),

- przyjść do normy (MB, 1903, 66) (SF, t. 1, s. 773: przyjść do równowagi),

- dojść do pięknego języka: „Gąssowski jest niezdrów na żołądek. [...] Ja również nie mogę dojść do pięknego języka" (MB, 1905, 125) (SF, t. 1, s. 176: dojść do zdrowia).

Licznie reprezentowana grupa frazeologizmów wskazuje, że Sienkiewicz chętnie sięgał po ten środek wyrazu w opisie realiów dotyczących zdrowia. Ponadto analizowane tu związki zróżnicowane pod względem semantycznym 
i formalnym (wyrażenia, zwroty, frazy) dzięki swym walorom obrazowym oraz potocznej proweniencj $\mathrm{j}^{14}$ wzmacniały ekspresję i zrozumiałość przekazywanych treści. Prócz frazeologizmów w postaci kanonicznej, takich jak: katar żołądka, pod psem, chuchać, dmuchać, poderwać zdrowie mamy formy zmodyfikowane. Wprowadzone przez Sienkiewicza modyfikacje służą ukonkretnianiu, precyzowaniu oraz aktualizacji wiadomości dotyczących zdrowia. Wśród odnotowanych przekształceń dominują innowacje wymieniające i rozwijające. Zwykle Sienkiewicz wprowadzał nacechowane zamienniki synonimiczne, np. wlazło zam. weszło, klapnać zam. zapaść, do pięknego języka zam. do zdrowia.

Pod względem kryterium semantycznego ${ }^{15}$ dominują frazeologizmy łączliwe. Konstrukcje tego typu umożliwiały Sienkiewiczowi tworzenie rozbudowanych ciągów synonimicznych, czasami o charakterze gradacyjnym, nazywających: chorobę, złe samopoczucie: nie mieć się dobrze, mieć się gorzej / nieszczególnie / dosyć marnie oraz zdrowie, dobre samopoczucie: mieć się dobrze / zupetnie dobrze / nieźle / lepiej / doskonale; czuć się dobrze / nieźle / zdrowym / zdrowszym, nie czuć się chorym.

Zgodnie z klasyfikacją funkcjonalną i genologiczną list prywatny jest tekstem użytkowym i należy do potocznej odmiany stylowej ${ }^{16}$. Słownictwo i środki wyrazu wchodzące w skład tworzywa językowego listów oprócz funkcji ekspresywnej służą także funkcji zabawowej, humorystycznej ${ }^{17}$. Sienkiewicz bardzo lubił żartować i miał duże poczucie humoru, o czym wiemy z przekazów potomnych, pośrednio również z lektury jego utworów ${ }^{18}$. W listach o problematyce zdrowotnej przykłady humoru słownego są bardzo częste. Przyjęta przez Sien-

${ }^{14}$ Przyjmuję za Jerzym Bartmińskim szerokie rozumienie potoczności, według którego język potoczny to język obiegowy, powszechny (J. Bartmiński, Styl potoczny, w: Wspótczesny język polski, red. J. Bartmiński, Wrocław 1993, s. 118, 115-132). W sposób równie szeroki pojęcie języka potocznego ujmuje Teresa Skubalanka. Zdaniem autorki język potoczny to język, mówiony, kolokwialny (język dialogów), nieoficjalny, ogólny (ogólnopolski), spontaniczny, szczególnie afektywny (ekspresywny) (Ekspresywność języka a mowa potoczna, w: Poetyka i stylistyka stowiańska, Wrocław 1973, s. 180).

${ }_{15}$ S. Skorupka, Wstęp, w: Stownik frazeologiczny języka polskiego..., s. 6.

${ }^{16}$ Pod względem doboru środków językowych i stylistycznych korespondencja Sienkiewicza realizuje wszystkie wyróżnione przez Bartmińskiego typy rejestrów potoczności (neutralny : emocjonalny; swobodny : staranny), ale z przewagą cech charakterystycznych dla rejestru emocjonalnego i starannego (zob. J. Bartmiński, Styl potoczny, w: Wspótczesny język polski, s. 120-124; Praktyczna stylistyka, red. E. Bańkowska, A. Mikołajczuk, Warszawa 2003, s. 72).

${ }^{17}$ Humor jest tu rozumiany jako forma komizmu; ujęcie w zabawny, żartobliwy sposób postaci, sytuacji. (Humor, Komizm [hasła], w: Słownik terminów literackich, red. J. Sławiński, Wrocław-Warszawa-Kraków-Gdańsk-Lódź 1988, s. 187, 230-231).

${ }^{18}$ Zob. M. Bokszczanin, Wstęp, w: Henryk Sienkiewicz, Listy, t. 2, cz. 1: Jadwiga i Edward Janczewscy, s. 102-104; T. Świętosławska, O stylu językowym Zagłoby w „Ogniem i mieczem” (w 110 rocznice Sienkiewiczowskiego arcydzieła), „Acta Universitatis Lodziensis. Folia Lingu- 
kiewicza strategia humorystycznego ujęcia tematu pozwalała mu rozładowywać napiętą atmosferę, łagodzić niepokój i smutek, czyli negatywne uczucia i stany towarzyszące zwykle sytuacjom związanym z chorobą bliskiej osoby.

Efekt humorystyczny osiągał pisarz głównie dzięki różnego typu przekształceniom semantycznym, metaforom (zwłaszcza animizacjom), porównaniom, eufemizmom, a także nawiązaniom do literatury oraz nielicznym neologizmom.

Do grupy określeń metaforycznych, użytych w funkcji humorystycznej, można zaliczyć następujące połączenia wyrazowe: nieporządki żoładkowe 'zaburzenia pracy żołądka': „Już myślałem, że wszystko dobrze, gdy wtem zaczęły się u Henia nieporządki żoładkowe" (JJ, 1898, 456), klepki w głowie bolaty: „Przyjechałem ze straszną migreną. Ucieszyli się tu do mnie znajomi bardzo, ale ja gadać nawet z nikim nie chciałem, bo mnie wszystkie klepki w głowie bolaty” (MB, 1888, 6), olowiany czepek na glowie: „Wczoraj nie piłem herbaty, a kawy czarnej tylko pół filiżanki - paliłem mało papierosów [...] i dziś nie mam olowianego czepka na głowie" (MSz, 1885, 10), cierpieć na sucho 'tzn. bez zastrzyknięcia morfiny jako środka uśmierzającego ból': ,[...] w nocy boli mnie, a nie mogę się namówić na zastrzyknięcie morfiny i wolę cierpieć na sucho" (JJ, 1895, 421). Szczególne miejsce wśród określeń metaforycznych zajmują animizacje, które w sposób żartobliwy nazywają różne schorzenia, dolegliwości i objawy chorób, np. ,serce skaczace” (MB, 1905, 112); „temperatura fantazjuje" (MB, 1910, 384); "nerwy rozkręcity mi się w ostatnich czasach bardzo" (MB, 1888, 6); „ból wędrowat z głowy, gdzie chcial” (JJ, 1895, 419); „mój sen to jest urwis, który co wieczór wylatuje gdzieś na bory, lasy i wcale do mnie nie

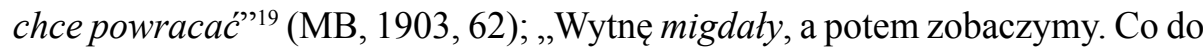
nich, zapowiedziałem im to, że ostatni raz zgrzeszyty” ${ }^{20}$ (JJ, 1894, 401); ,Jest to w każdym razie jakiś rodzaj odry-a jeśli nie odra to jej młodsza kuzynka, więc myślałem, że Dzince nic nie będzie” (JJ, 1898, 456); „Dla Twoich newralgii mam anielskie współczucie, albowiem doświadczam zupełnie takich samych. Boli mnie bok, czasem i noga. Przechodzi to z jednej strony na druga, zmienia się, zbliża lub oddala od krzyża, słowem, tańczy, jak samo chce" (JJ, 1897, 439); „Jeszcze jestem w Krakowie, bo reumatyzm w głowiźnie nie puszcza. Wczoraj wlazł w ramię, dziś znowu puka po głowie, choć mniej silnie niż poprzednio" (JJ, 1890, 262); „Zyskałem już 4 kilo i staję się szpetnie otyłym. Winternitz ${ }^{21}$ kontent ze mnie, a jednak czuję jeszcze od czasu do czasu w żołądeczku coś jakby rodzaj gorzkich wymówek, że go zmuszam do pracy nad sity" (JJ, 1892, 321);

\footnotetext{
istica” 1996, nr 35, s. 29-37; A. Wilkoń, O języku i stylu „Ogniem i mieczem” Henryka Sienkiewicza. Studia nad tekstem, Kraków 1976. (Zeszyty Naukowe UJ 427. Prace Językoznawcze, z. 50).

${ }_{19}$ Sienkiewicz bardzo często cierpiał na bezsenność.

${ }^{20}$ Operacji migdałów Sienkiewicz poddał się w marcu 1895 roku.

${ }^{21}$ Wilhelm Winternitz - lekarz hydropata, przyjaciel Sienkiewicza.
} 
„Z listu mateczki [...] wiemy, że pozwalasz sobie na to samo co ja i że zamierzałaś mieć influencę. Ja to zamierzam od tygodnia, a przynajmniej mam katar, który $w$ dzisiejszych czasach blagi i pozy może śmiało pozować na influencę" (JJ, 1910, 504); „Obudziłem się dziś rano z chrypką i iszjasem. Gdybyś nie mogła, to przyjdziemy do Was, to jest: ja, chrypka i iszjas" (MB, bez daty, 569).

Prócz metafor animistycznych źródłem humoru słownego i ekspresji są porównania, np. „Kaślę bardzo i połamany jestem przez influencę jak stara laska” (JJ, 1893, 356), „krzyż boli jak starego dziada” (MB, 1903, 68), „Kaśle jak owca, piersi mnie bolą” (JJ, 1894, 368), „czuję się tak, jakby mnie kijem obito” (MB, 1909, 316), „Zdziś cały jest okryty pryszczami - opryszczony jak nieboskie stworzenie” (JJ, 1890, 202), „W domu wszyscy się dobrze mają, prócz $p$. May, która także jest zdrowa, ale chrypi jak przedęta trąbka dziecinna" (MB, 1904, 103), „Jak się miewasz, jak sypiasz, czy jesteś zdrowa? Gdym wyjeżdżał, wygladałaś jak niedomalowana figurka saska" (MB, 1900, 26), „Powłoka moja materialna jest nieco zmęczona i niezbyt zdrowa, spiritus za to zmęczony jak to psisko" (JJ, 1888, 125). Analiza przywołanych przykładów wskazuje, że w określaniu realiów związanych ze zdrowiem Sienkiewicz wykorzystywał głównie porównania potoczne, utarte i raczej szablonowe. Pod względem formalnym realizują one klasyczny model tego środka stylistycznego, z łącznikiem jak. Wśród zgromadzonych przykładów oryginalnością doboru elementów zestawienia odznacza się porównanie: ,żoładek mój zachowuje się tak jak Wolff $i$ Schönerer, razem wzięci, w parlamencie austriackim" (JJ, 1897, 450). Aby właściwie odczytać tertium comparationis porównania i poprawnie zinterpretować przedstawioną przez Sienkiewicza sytuację zdrowotną należy odnieść się do realiów XIX-wiecznej polityki europejskiej. Otóż wymienione w porównaniu osoby to politycy, którzy tworzyli w parlamencie wiedeńskim silną opozycję wobec liberalnych tendencji Austrii, działającą poprzez obstrukcję. Kluczem do ujawnienia związków semantycznych i źródła dowcipu jest polisem obstrukcja, który ma dwa znaczenia: 1) 'krępowanie, mitrężenie rozpraw w parlamencie w celu zyskania na czasie a zniewolenia przeciwników do ustępstw', 2) 'lek. zatwardzenie, zapieczenie stolca'22. W informacjach na temat różnych objawów chorobowych Sienkiewicz zawsze starał się unikać biologizmu i opisów naturalistycznych. Zasady tej przestrzegał zwłaszcza w listach adresowanych do szwagierki, której specyficzne preferencje estetyczne były mu dobrze znane ${ }^{23}$. Dzięki pomysłowej, oryginalnej formie porównania pisarz

${ }^{22}$ Stownikjęzyka polskiego, red. A. Karłowicz, A. Kryński, W. Niedźwiedzki, t. 3, Warszawa 1904, s. 522.

${ }^{23}$ Janczewska nie tolerowała naturalizmu w żadnej dziedzinie życia, odrzucała wszelkie przejawy biologizmu (zob. L. Mariak, „Żaba” $i$,,Mgła” - językowa kreacja Jadwigi Janczewskiej..., passim). 
w sposób omowny i elegancki zarazem poinformował adresatkę o swojej bardzo prozaicznej przypadłości gastrycznej.

Pozostając w kręgu podjętych tu rozważań, należy podkreślić, że eufemistyczne ujęcie opisu różnych dolegliwości jest zabiegiem często stosowanym przez Sienkiewicza. Wynika ono przede wszystkim z charakteru i, jak to pisarz sam określił: „,wersalskiego usposobienia” (MB, 1890, 227), które „nie pozwalało mu szerzej mówić" o zbyt intymnych, wstydliwych lub prozaicznych szczegółach związanych z chorowaniem. Omowną formę zastosował pisarz w przypadku takich schorzeń, objawów, stanów i czynności fizjologicznych, jak:

a) biegunka:

- ,Z niewiadomych przyczyn niedyspozycja żołądkowa od rana. [...] Od rana do trzeciej był trzy razy niepokój; od trzeciej cisza. - Pozostało tylko wzdęcie - i uczucie głodu [...] (MB, 1911, 467),

- „Ja także przyjąłem medykament, po którym bezpieczniej jest domu nie opuszczać" (MB, 1899, 21),

- ,[...] zdecydowałem się na 3 kapsułki popite kwiatem. Dziś rano skutek trzykrotny. Nie czuję się już tak nadęty jak poprzednio" (MB, 1913, 500),

- ,Wody piję, ale wywołują one pewne zaburzenia, o których moje wersalskie usposobienie nie pozwala mi szerzej mówić" (MB, 1890, 227);

b) wypróżnienie:

- „Zdrowie moje dobre - dolegliwości minęły wypędzone przez pulvis liquiritiae compositum ['środek przeczyszczający' - L.M.] z ogromnym impetem. (JJ, 1889, 183),

- „Powiedz Edwardowi ode mnie jedną rzecz. Chorowałem kilka razy na nerwy. Dręczyła mnie wówczas ogromna bezsenność, ale pomogła mi..., jak by to napisać... pomogła mi pewna zmiana w czynnościach życiowych, a mianowicie przełożenie porannych na wieczór, przed pójściem spać. Wydaje się to drobiazgiem, a jednak naprawdę ten prosty, a bardzo pomocny sposób może doktorom nie przyjść do głowy” (JJ, 1913, 514);

c) wymioty spowodowane chorobą morską:

- ,[...] przyjeżdżają do nas «Dzinią» [statek należący do Abakanowiczów, nazwany imieniem córki Sienkiewicza - L.M.], ofiarując po drodze bogom morskim to, co na śniadanie zjedli (HS, 1898, 16), Niedziela do 1-szej zeszła na pokładzie, gdzie kołysanie wynagradza świeże powietrze. Widzieliśmy jakąś hrabinę bawarska jedzącą i chorującą na przemian - to jest latająca od talerza do poręczy statku i znów do talerza" (JJ, 1886, 35); 
d) zawansowana ciąża:

- „Widziałem wczoraj Pstrokońskich, którzy byli u nas wieczorem na obiedzie. Ona bardzo już ubłogostawiona, ale nieźle wygląda" (JJ, 1911, 419);

e) otyłość:

- „Pietrusia jest zdrowa i podobna - jeśli nie do stulistnej róży, to przynajmniej do petnej georginii albo do stonecznika" (MB, 1908, 238);

f) menstruacja:

- „Do Zakopanego jutro ani pojutrze, jak miałem zamiar, nie wyjeżdżam, gdyż Babunia powiedziała mi, że w tych czasach «przechodzi ona [córka Jadwiga - L.M.] mała przypadłość», a jakoby ona sama miała mówić, że podróż «w takich razach» ją męczy” (MB, 1909, 354).

Eufemistyczny sposób przekazywania informacji o fizjologicznych aspektach chorowania i innych funkcjach ciała jest zdeterminowany głównie względami estetycznymi oraz chęcią rozładowania napięcia i wywołania u odbiorców odpowiednich reakcji, zwłaszcza śmiechu, wesołości.

Zwiększoną wartością ekspresywną odznaczają się fragmenty listów, w których Sienkiewicz w sposób celowy wyolbrzymiał skutki lub objawy opisywanych chorób i dolegliwości. Przesadne podkreślenie skali jakiegoś zjawiska chorobowego pozwalało mu pozbyć się ujemnych emocji i osiągnąć efekt komiczny. Z komizmem wywołanym przez zjawisko hiperboli mamy do czynienia przy prezentacji wielu schorzeń. Najczęściej jednak omawiany tu zabieg stylistyczny towarzyszył opisowi bardzo prozaicznego i powszechnego schorzenia, jakim jest katar. Wyraźnie wyolbrzymiony, oparty na kontraście sposób ujęcia objawów kataralnych dowodzi, że to schorzenie bardzo Sienkiewiczowi dokuczało: „[... [ mam katar, jakiego by się żaden król w chrześcijaństwie nie powstydzip” (JJ, 1888, 103); ,[...] mimo paltota przeziębiłem się, wskutek czego od wczoraj mam okropny katar z bólem kości, oczu, głowy i z powodzia...”" (JJ, 1888, 132); Katareczek nie powinien się zmieniać w katar, a katar w katarzysko (JJ, 1890, 238); „Na szczęście okazało się dziś, że to tylko katar, który też zmienił się w płynący - i w tej chwili upusty mego nosa sa tak otwarte, że używam wszelkich ostrożności, aby Ci nie złożyć dotykalnych tego dowodów" (JJ, 1887, 91); „Obroniłem się wprawdzie od gorączki, ale bolały mnie zęby, szczęki, oczy, głowa i cieszyłem się łamaniem w kościach. Do wczoraj nie wychodziłem i bole przeszły, ale nos pozostat stolica kataru [...]" (JJ, 1910, 504). Hiperbolizacja i wynikający z niej komizm ma swoje źródło głównie w odpowiednio dobranej i ukształtowanej stylistycznie warstwie leksykalnej. Wśród użytych środków językowego wyrazu można wymienić np. gradację (katareczek $\rightarrow$ katar $\rightarrow$ kata$r z y s k o$ ), słownictwo wartościujące z wpisanym semem intensywności cechy 
(okropny katar, upusty nosa, powódź), wyliczenie (okropny katar z bólem kości, oczu, głowy i z powodzia, bolaty mnie zęby, szczęki, oczy, głowa i cieszyłem się tamaniem $w$ kościach) oraz amplifikację (katar, jakiego by się żaden król w chrześcijaństwie nie powstydzit, nos - stolica kataru).

$\mathrm{Z}$ funkcją humorystyczną i ekspresywną związane są również różnego typu nawiązania, aluzje, trawestacje literackie. Sienkiewicz często odwoływał się do dzieł wielkich pisarzy, aby w wyniku kontrastowego zestawienia stylu wysokiego (fragment tekstu literackiego) i stylu niskiego (realia związane z chorobą, zwykle prozaiczną) uzyskać komiczny efekt:

Tabela 2. Nawiązania, aluzje, trawestacje literackie w funkcji humorystycznej

\begin{tabular}{|c|c|c|}
\hline Cytat i lokalizacja & Źródło odniesienia & Cel/interpretacja \\
\hline $\begin{array}{l}\text { „Naprzód jak się miewasz } \\
\text { i czy dobrze spałaś, bo } \\
\text { wczoraj miałaś taką postać, } \\
\text { jakbyś się chciała do } \\
\text { poduszki dostać” (MB, bez } \\
\text { daty, 566). }\end{array}$ & $\begin{array}{l}\text { Nawiązanie do Marii } \\
\text { Antoniego Malczew- } \\
\text { skiego: „Mario, czyś ty } \\
\text { nie chora? bo masz taką } \\
\text { postać / Jakbyś się do } \\
\text { Aniołów pragnęła już } \\
\text { dostać” }{ }^{23} \text {. }\end{array}$ & $\begin{array}{l}\text { Żartobliwy opis mizer- } \\
\text { nego wyglądu żony - } \\
\text { Marii z Babskich. }\end{array}$ \\
\hline $\begin{array}{l}\text { „[...] nie jadłem bigosu, } \\
\text { za co, wyobraź sobie, } \\
\text { Bauerertz }{ }^{24} \text { mnie wyła- } \\
\text { jał - i z żołądkiem zająłem } \\
\text { mniej więcej pożądane sta- } \\
\text { nowisko między hr. Hen- } \\
\text { rykiem a Pankracym [...]" } \\
(\mathrm{JJ}, 1892,323) .\end{array}$ & $\begin{array}{l}\text { Nawiązanie do Nie- } \\
\text {-Boskiej komedii } \\
\text { Zygmunta Krasińskiego. } \\
\text { Stanowisko, o którym } \\
\text { wspomina Sienkiewicz, } \\
\text { to stanowisko pośrednie, } \\
\text { dalekie od krańcowości, } \\
\text { jakie w dramacie repre- } \\
\text { zentują hrabia Henryk, } \\
\text { arystokrata należący do } \\
\text { obozu konserwatywnego, } \\
\text { i Pankracy - przywódca } \\
\text { rewolucjonistów. }\end{array}$ & $\begin{array}{l}\text { Żartobliwy opis stanu } \\
\text { żołądka pisarza; jest to } \\
\text { wprawdzie stan daleki } \\
\text { od doskonałości, ale też } \\
\text { nie najgorszy. }\end{array}$ \\
\hline $\begin{array}{l}\text { „[...] - byłem jak «ojciec } \\
\text { zadżumionych». Miałem } \\
\text { dowody, jak nadzwyczaj- } \\
\text { nie udziela się ten rodzaj } \\
\text { wysypki czy odry, na którą } \\
\text { dzieci chorowały i nie } \\
\text { chciałem jej przesłać Tobie } \\
{[\ldots] ”(\mathrm{JJ}, 1898,456) .}\end{array}$ & $\begin{array}{l}\text { Nawiązanie do poematu } \\
\text { Juliusza Słowackiego } \\
\text { Ojciec zadżumionych. }\end{array}$ & $\begin{array}{l}\text { Żartobliwa autocha- } \\
\text { rakterystyka wyglądu } \\
\text { pisarza, którego skóra } \\
\text { pokryta była wysypką. }\end{array}$ \\
\hline
\end{tabular}

${ }^{24}$ A. Malczewski, Maria, pieśń XVII, w. 537-538.

${ }^{25}$ Adam Bauerertz - lekarz warszawski, przyjaciel Sienkiewicza. 


\begin{tabular}{|c|c|c|}
\hline Cytat i lokalizacja & Źródło odniesienia & Cel/interpretacja \\
\hline $\begin{array}{l}\text { „Co dzień przy tym mam } \\
\text { bardzo przykre i depry- } \\
\text { mujące artretyczne bole } \\
\text { głowy, a w ostatnich } \\
\text { czasach coś się popsuło } \\
\text { i w tym państwie, w któ- } \\
\text { rym pod wpływem } \\
\text { kwaśnego mleka wszystko } \\
\text { już było dobrze” (JJ, 1908, } \\
\text { 489). }\end{array}$ & $\begin{array}{l}\text { Nawiązanie do kwestii } \\
\text { Marcellusa z I aktu Ham- } \\
\text { leta Wiliama Szekspira: } \\
\text { „Coś się popsuło w pań- } \\
\text { stwie duńskim”25. }\end{array}$ & $\begin{array}{l}\text { Żartobliwy opis } \\
\text { nawrotu zaburzeń } \\
\text { żołądka. }\end{array}$ \\
\hline $\begin{array}{l}\text { „Co do zdrowia mego } \\
\text { w ogóle, przychodzą mi } \\
\text { zawsze na myśl słowa } \\
\text { Szekspira, które Falstaff } \\
\text { wypowiada do Lorda- } \\
\text {-Sędziego: «Wasza } \\
\text { Dostojność jakkolwiek } \\
\text { niezupełnie jeszcze poza } \\
\text { granicami młodości, } \\
\text { czuje już jednak pewne } \\
\text { podmuchy wieku, pewien } \\
\text { smaczek soli czasu», otóż } \\
\text { ten «smaczek» odczuwam } \\
\text { na równi z lordem, który } \\
\text { zresztą nie był ode mnie } \\
\text { młodszy. Te «podmuchy» } \\
\text { są raz wraz inne. W tej } \\
\text { chwili na przykład wlazło } \\
\text { mi coś między łopatki } \\
\text { w krzyż i od wczoraj rana } \\
\text { odczuwam taki ból, że } \\
\text { ledwo piszę” (JJ, 1912, } \\
\text { 510). }\end{array}$ & $\begin{array}{l}\text { Słowa Falstaffa, skiero- } \\
\text { wane do Lorda Wiel- } \\
\text { kiego Sędziego z dra- } \\
\text { matu Wiliama Szekspira } \\
\text { Henryk IV: „Wasza } \\
\text { Dostojność, choć jeszcze } \\
\text { niezupełnie za granicami } \\
\text { młodości, czuje pewne } \\
\text { podmuchy wieku, mały } \\
\text { smaczek soli czasu”26. }\end{array}$ & $\begin{array}{l}\text { Żartobliwa autocha- } \\
\text { rakterystyka niezbyt } \\
\text { dobrego samopoczucia } \\
\text { Sienkiewicza, spowo- } \\
\text { dowanego wiekiem } \\
\text { i wieloma różnymi } \\
\text { dolegliwościami. }\end{array}$ \\
\hline
\end{tabular}

Zaprezentowany - jedynie wybiórczo - przegląd cytatów i nawiązań do literatury rodzimej oraz światowej dowodzi ogromnego oczytania pisarza, a także umiejętności twórczego wykorzystania tego źródła jako inspiracji w opisie realiów związanych ze zdrowiem.

${ }^{26}$ W. Szekspir, Hamlet, akt I, scena 4, thum. J. Kasprowicz, Lwów 1890, s. 87.

${ }_{27}$ W. Szekspir, Henryk IV, cz. 2, akt I, scena 2, thum. L. Ulrich, w: Dzieła dramatyczne, t. 3, Warszawa 1963, s. 362. 


\begin{tabular}{|l|l|l|}
\hline Cytat i lokalizacja & Źródło odniesienia & Cel/interpretacja \\
\hline „Kończę, bo szczerze & Nawiązanie do twórczo- & Obrazowy i sugestywny \\
Ci mówię, że z wyczer- & ści własnej - Bukacki, to & opis usytuowania bólu \\
pania nie mogę pisać & bohater Rodziny Poła- & głowy, który często \\
dalej - i głowa pobolewa & nieckich, który często & dokuczał pisarzowi. \\
mnie jak Bukackiego - & uskarżał się na bóle & \\
z tyłu” (JJ, 1895, 427). & w tyle głowy. & \\
\hline
\end{tabular}

Na zakończenie podjętych tu rozważań warto wspomnieć o niewielkiej grupie trzech neologizmów ${ }^{28}$, które znalazły się w zasobie leksyki z zakresu medycyny. Są to, oprócz wymienionego wcześniej imiesłowu ubłogosławiona 'w stanie błogosławionym, w ciąży', malwa ${ }^{29}$ oraz neosemantyzm tutti frutti ${ }^{30}$. Obu form używał Sienkiewicz na określenie specyficznego stanu, gdy chorował na kilka różnych schorzeń jednocześnie, np. „Ze mną malwa. Mam katar żołądka, a prawdopodobnie i kiszek, powiększenie śledziony, wątroby, nieregularny obieg krwi, zawroty głowy, bicie serca, słowem tutti frutti. Krótko mówiąc: malwa!" (JJ, 1892, 319).

\section{$* * *$}

Korespondencja adresowana do najbliższych oprócz rzeczowych informacji na temat zdrowia członków rodziny, przyjaciół i samego pisarza zawiera wiele ważnych wskazówek pozwalających odczytać uczucia, które towarzyszyły Sienkiewiczowi podczas pisania listów o takiej tematyce. Analizowane przykłady dowodzą, że Sienkiewicz bardzo emocjonalnie podchodził do omawianych w listach kwestii zdrowotnych i chętnie dzielił się z rodziną swoimi spostrzeżeniami oraz uczuciami. Świadczy o tym bogata, zróżnicowana i nacechowana ekspresywnie warstwa leksykalna.

${ }^{28}$ Zaliczyłam tu wyrazy niepoświadczone w SW i w Słowniku języka polskiego pod redakcją Witolda Doroszewskiego (Warszawa 1958-1969, t. 1-11).

${ }^{29}$ Nie jest znana motywacja tego neologizmu, często używanego przez pisarza na określenie czegoś złego, brzydkiego, np. stanu zdrowia, pogody itp. Być może Sienkiewicz wykorzystał tu ang. przymiotnik malevolent - 'wrogi, złośliwy' - lub rzeczownik malevolence - 'wrogość, złośliwość'. Z uwagi na nieoficjalny i zindywidualizowany charakter, nacechowanie ekspresywne oraz użycie w komunikacji prywatnej, wyraz ten można zaliczyć do języka familijnego rodziny Sienkiewiczów (zob. K. Handke, Socjologia języka, Warszawa 2008, s. 79-90).

${ }^{30}$ Tutti frutti (wł.) - mieszanina wszystkich owoców; u Sienkiewicza: mieszanina chorób. 


\section{Leonarda Mariak}

\section{The Expressive Function of Medical Lexis in Henryk Sienkiewicz's Private Letters}

This article contains an analysis of medical lexis conducted in connection with the expressive function performed by this verbal layer.

The collected lexical and stylistic material includes expressions and phrases with expressively characterized adjectives and adverbs, expressive and diminutive derivatives, compounds, different stylistic means (e.g., metaphors, comparisons, euphemisms and other).

KEYWORDS: stylistics, lexis, private correspondence, expression, verbal humour.

dr hab. Leonarda Mariak - Zakład Historii Języka Polskiego, Instytut Polonistyki i Kulturoznawstwa, Uniwersytet Szczeciński; zainteresowania naukowe: XIX-wieczna polszczyzna, prasa z tego okresu, zwłaszcza język tekstów Henryka Sienkiewicza i Stefana Żeromskiego. 